\title{
TRADITIONAL ISLAMIC EXCLUSIVISM - A CRITIQUE
}

\author{
IMRAN AIJAZ \\ University of Michigan-Dearborn
}

\begin{abstract}
In this paper, I give an account and critique of what I call 'Traditional Islamic Exclusivism' - a specific Islamic interpretation of religious exclusivism. This Islamic version of religious exclusivism rests on exclusivist attitudes towards truth, epistemic justification and salvation. After giving an account of Traditional Islamic Exclusivism by explaining its theological roots in the Qur'an and ahadith (reports of sayings attributed to the Prophet Muhammad), I proceed to critique it. I do so by arguing that Islamic epistemic exclusivism, which forms the main core of Traditional Islamic Exclusivism, is implausible. This criticism subsequently opens up further lines of criticism and discussion of both salvific and alethic exclusivism in an Islamic context. I conclude with some remarks about the implications and significance of my criticisms of Traditional Islamic Exclusivism.
\end{abstract}

\section{INTRODUCTION}

Contemporary Philosophy of Religion has seen a lot of discussion surrounding religious exclusivism, mainly due to the fact that philosophers of religion have, over the last few decades, started to take seriously the rich diversity in beliefs about religion. As John Hick explains, for a long time the labels 'Philosophy of Religion' and 'Philosophy of The Christian Religion' were treated as synonymous. ${ }^{1}$ It is only during the last couple of decades that philosophers of religion in the West have, in Hick's words, increasingly felt obliged to take note of the fact that Christianity is only one of the great world faiths and that monotheism is only one of the

${ }^{1}$ John Hick, 'Religious Pluralism', in Charles Taliaferro et al., A Companion to The Philosophy of Religion, Second Edition (Oxford: Blackwell Publishing, 2010), pp. 710-17 (p. 710). 
major types of religion.' According to many philosophers of religion such as Hick, incorporating facts about the world's religious diversity into an assessment of the plausibility of religious claims is important. It also calls into question the reasonableness of maintaining an exclusivist attitude in religious matters.

But what is religious exclusivism? Even just a cursory survey of the relevant literature reveals that there is no consensus on how to understand it and that it is construed in a variety of different (and sometimes confusing) ways. David K. Clark, for example, understands it as follows: 'Only one true religion leads to God. Attaining the spiritual goal requires a believer to find and follow the one true faith, for other religious paths will not lead to the spiritual goal. ${ }^{3}$ Discussing religious exclusivism specifically within an Islamic context, Zain Ali defines what he calls 'Muslim Exclusivism' as follows: 'Islamic theism is overall epistemically superior $[s i c]$ and that all other incompatible beliefs are false. ${ }^{4}$ In just these two definitions alone, we see that religious exclusivism can be understood with reference to three distinct matters, even if they are conceptually connected: truth, epistemic justification and salvation.

In this paper, I will discuss religious exclusivism in an Islamic context. In particular, I will focus on exclusivism with respect to truth, epistemic justification and salvation in the Islamic religion - three tiers that form the basis of what I will call 'Traditional Islamic Exclusivism'. I will give an account of Traditional Islamic Exclusivism by basing it on the traditional Islamic understanding of religious truth, epistemic justification and salvation, after which I will proceed to critique it. I will then conclude with some remarks about the implications and significance of my assessment of Traditional Islamic Exclusivism.

\section{TRADITIONAL ISLAMIC EXCLUSIVISM EXPLAINED}

I will give the label Traditional Islamic Exclusivism to a view that, as I shall construe it, is comprised of a conjunction of three distinct positions situated within an Islamic context and based on traditional

${ }^{2}$ Ibid.

3 David K. Clark, 'Religious Pluralism and Christian Exclusivism', in Francis J. Beckwith et al., To Everyone An Answer, (Downers Grove, IL: InterVarsity Press, 2009), pp. 291-307 (p. 293).

4 Zain Ali, Faith, Philosophy and The Reflective Muslim (Basingstoke: Palgrave Macmillan, 2013), p. 138. 
Islamic understanding: (1) alethic exclusivism, (2) epistemic exclusivism and (3) salvific exclusivism. Let me explain these in turn.

\subsection{Alethic Exclusivism}

First, I understand alethic exclusivism as follows. A person is an alethic exclusivist with respect to a proposition $p$ if and only if, in believing that $p$ is true, she takes to be false any beliefs that are incompatible with $p$. Thus understood, alethic exclusivism sounds obviously true and uncontroversial; indeed, it seems to be one of the fundamental principles that guide our reasoning. We believe in the falsity of propositions like 'Abraham Lincoln is alive' or 'George W. Bush is the President of The United States' precisely because we believe that the propositions 'Abraham Lincoln is dead' and 'Barack Obama is the President of The United States' are true. Those who subscribe to alethic exclusivism within an Islamic context will maintain the falsity of those beliefs that are incompatible with Muslim belief. For example, the Muslim alethic exclusivist will believe in the falsity of the propositions 'Zeus exists' or 'Jesus is the son of God' because their falsity is entailed by Muslim belief.

In addition to being a basic principle underlying rationality, alethic exclusivism also follows from a natural interpretation of the primary source of authority in Islam, the Qur'an. In reading the Islamic Scripture, one will constantly find denials of religious propositions that are incompatible with those that are affirmed as part of Islamic belief. In affirming the existence of Allah as the only God, for instance, the Qur'an denies the existence of any other deity (2:163). Or, to consider another example, in affirming the strict Islamic understanding of God's (indivisible) oneness (112:1), the Qur'an rejects the Christian doctrine of the Trinity (4:171). Many more examples of this sort can be found in the text.

\subsection{Epistemic Exclusivism}

Next, epistemic exclusivism. It is epistemic exclusivism that, as I see it, provides the principle basis and spirit of religious exclusivism in Islam. As with alethic exclusivism, epistemic exclusivism can be understood more generally without reference to religion. Here is how I will construe it. A person is an epistemic exclusivist with respect to proposition $p$ if and only if, in believing that epistemic justification exists for $p$, she rejects the existence of epistemic justification for any propositions incompatible 
with $p$. Why would a person be attracted to epistemic exclusivism, thus understood? There are a few possible answers. One that is pretty common is when a person believes that the epistemic justification for $p$ is so strong or overwhelming that the existence of epistemic justification for propositions incompatible with $p$ is highly unlikely. ${ }^{5}$ As an example, consider Richard Dawkins' views about evolution and Young-Earth creationism, two incompatible perspectives about the origins of life and species on our planet. In his book The Greatest Show on Earth, ${ }^{6}$ Dawkins states that ' $\mathrm{t}$ ] he evidence for evolution grows by the day, and has never been stronger ... the "theory" of evolution is actually a fact - as incontrovertible a fact as any in science." He compares those who would deny evolution to people who believe that the Roman Empire never existed or that the Holocaust never happened. ${ }^{8}$ Indeed, for Dawkins, the evidence for evolution is so strong that, as he stated controversially in 1989 , 'It is absolutely safe to say that if you meet somebody who claims not to believe in evolution, that person is ignorant, stupid or insane (or wicked, but I'd rather not consider that). ${ }^{9}$ Furthermore, given his belief in the preponderance of evidence supporting evolution, Dawkins has always maintained that any 'evidence' to the contrary, particularly in support of Young-Earth creationism, is virtually non-existent. For instance, he states more recently: 'Just as I wouldn't expect a gynaecologist to have a debate with somebody who believes in the Stork-theory of reproduction, I won't do debates with Young Earth creationists.' ${ }^{10}$

The kind of epistemic exclusivism that I have described here is evident in traditional Islamic belief. Consider the two core beliefs

${ }^{5}$ It may be helpful to compare Gilbert Harman's explanation of how one can dismiss alleged evidence for not- $p$ as 'misleading' in cases where one actually knows $p$ : 'If I know that $h$ is true, I know that any evidence against $h$ is evidence against something that is true; so I know that such evidence is misleading. See Gilbert Harman, Thought (Princeton, NJ: Princeton University Press, 1973), p. 148.

${ }^{6}$ Richard Dawkins, The Greatest Show on Earth: The Evidence for Evolution, (New York: Free Press, 2010).

7 Ibid., p. vii.

8 Ibid., pp. 3-4.

9 Richard Dawkins, 'Ignorance is No Crime', The Richard Dawkins Foundation, available at: <http://old.richarddawkins.net/articles/114> (last accessed 1/30/14).

${ }^{10}$ Stoyan Zaimov, 'Richard Dawkins Explains Why He Doesn't Debate Young-Earth Creationists', The Christian Post, available at: <http://www.christianpost.com/news/ richard-dawkins-explains-why-he-doesnt-debate-young-earth-creationists-107196/> (last accessed 1/30/14). 
of the Islamic religion that are expressed in the Shahada, the Muslim declaration of faith ${ }^{11}$ - belief in the existence and oneness of God and belief in Muhammad as God's Prophet. Both the Qur'an and the ahadith are clear that there is very strong epistemic justification for both of these beliefs and very little, if any, for those beliefs incompatible with them. In what follows, I will itemize (in no particular order) the different types of epistemic justification for belief in the existence and oneness of God as well as belief in Muhammad as God's Prophet, according to traditional Islamic understanding:

(1) Belief in God as Our Original, Natural Disposition (Fitrah): In a well-known hadith, the Prophet Muhammad is reported to have said: 'Every child is born with a true faith of Islam [fitrah] ... but his parents convert him to Judaism, Christianity or Magianism, as an animal delivers a perfect baby animal. Do you find it mutilated?'12 The reference to fitrah is a reference to what, according to Islamic tradition, is our original disposition to recognize and worship only God (i.e. to be Muslims). The Qur'an also affirms this understanding of the term: 'So direct your face toward the religion, inclining to truth. [Adhere] to the fitrah of Allah upon which He has created [all] people. There is no altering of Allah's creation.' (30:30) For this reason, many individuals who come to Islam after leaving their non-Islamic faith or worldview refer to themselves as reverts and not converts; ${ }^{13}$ the idea here is that such individuals are returning to their original disposition to be Muslims. One way that the concept of fitrah can be used to support Islamic epistemic exclusivism is as follows: While belief in the existence and oneness of Allah is our natural disposition, beliefs that are incompatible with this cornerstone of Islamic doctrine can be dismissed as epistemically unjustified, as they are held merely on the basis of taqlid (imitation). ${ }^{14}$

11 Translated into English, the Shahada reads as follows: 'There is no god but God, Muhammad is the Messenger of God.'

12 Sahih Bukhari, 2:441, available at: <http://www.sacred-texts.com/isl/bukhari/bh2/ bh2_442.htm> (last accessed 1/30/14).

${ }^{13}$ See, for example, '10 embrace Islam in Riyadh', Arab News, Tuesday, 4 February, 2014, available at: <http://www.arabnews.com/news/520291> (last accessed 2/5/2014). A search for the word 'revert' on this website's search engine brings up dozens of stories of people 'reverting' to Islam.

${ }_{14}$ The term is typically used by Muslim apologists in a pejorative sense and as a synonym for 'blind belief/faith'. See Al-Ghazali's discussion of taqlid as a belief forming mechanism to be contrasted with fitrah in his 'Deliverance from Error', in W. Montgomery Watt, The Faith and Practice of Al-Ghazali (London: G. Allen and Unwin, 1967), p. 21. 
(2) The 'Islamic Anthropological Argument': A further component of epistemic justification for the Muslim view that Islam is our primordial religion comes by way of what I shall term The 'Islamic Anthropological Argument.' In essence, the argument maintains that every nation on earth was sent a messenger calling people to worship Allah alone and to shun all false deities (e.g. see Qur'an 10:47, 16:36 and 35:24). Some of these messengers are mentioned by name in the Qur'an while others are not, a point acknowledged explicitly in the text itself (40:78). The Islamic Anthropological Argument serves to augment the Muslim understanding of fitrah by pointing out that the messengers of God were sent to people of all nations to bring them back to the straight path of Islam (Quran 2:213). Islamic tradition maintains that our natural disposition is to worship God alone, even if it is subsequently corrupted. The pagan Arabs of Muhammad's time, for instance, acknowledged that God owns all that is in the heavens and the earth; that He is the Lord of the seven heavens; and, that in His Hand is dominion over all things. Despite believing all of this, they dismissed the (Islamic) belief in bodily resurrection as false. In noting all this, the Qur'an labels them as deluded and liars (23:81-89).

(3) Qur'anic Arguments for The Existence and Oneness of God: The Qur'an presents two main arguments for the existence of God as further sources of epistemic justification for Islamic belief. The Spanish Muslim philosopher, Ibn Rushd (Averroes), provides a helpful discussion of these two arguments in his The Exposition of The Methods of Proof..$^{15}$ According to Ibn Rushd, the two main Qur'anic arguments for the existence of God are best understood as arguments from providence and invention. Based on his discussion, ${ }^{16}$ we can present these arguments in standard form as follows:

The Argument from Providence

(1) All existing things (found in the world) are suited to man's existence.

(2) Things that are suitable for man's existence are necessarily so due to an Agent both willing and intending such suitability. a. The suitability in question cannot be due to chance.

${ }^{15}$ See the translation of this work in Ibrahim Y. Najjar, (trans.), Faith and Reason in Islam (Oxford: Oneworld, 2001).

${ }^{16}$ Ibid., pp. 33-34. 
(3) (Therefore) There exists an Agent (i.e. God) who providentially ordered the world for man.

\section{The Argument from Invention}

(1) All existing things (animals, plants, etc.) are invented.

(2) For everything invented, there is an inventor.

(3) (Therefore) There exists an Inventor (i.e. God) of every existing thing in the world.

After giving an account of The Argument from Providence and The Argument from Invention, Ibn Rushd maintains that these two arguments 'are the arguments favoured by religion. ${ }^{17}$ Qur'anic verses drawing our attention to evidence that points to the existence of God refer to (1) The Argument from Providence (e.g. 78:6-16), (2) The Argument from Invention (e.g. 86:5, 88:17, 22:73) or (3) a combination of The Argument from Providence and The Argument from Invention (e.g. 2:20-23). ${ }^{18}$

The Qur'an also presents some arguments for the oneness of God and against polytheism. The seeds of these arguments are found in verses like: 'Say: If there had been (other) gods with Him, as they say, behold, they would certainly have sought out a way to the Lord of the Throne!' (17:42); and, 'If there were therein gods beside Allah, then verily both (the heavens and the earth) would have been disordered. Glorified be Allah, the Lord of the Throne, from all that they ascribe (unto Him).' (21:22) Verse 23:91 explicitly repudiates the Christian doctrine of the divinity of Jesus as well as the doctrine of the Trinity: 'Allah has not taken any son, nor has there ever been with Him any deity. [If there had been], then each deity would have taken what it created, and some of them would have sought to overcome others. Exalted is Allah above what they describe [concerning Him].' Based on such verses, Muslim thinkers like 'Abd al-Jabbar and al-Ghazali formulated sophisticated arguments for the conclusion that there can be only one divine being. ${ }^{19}$

(4) The 'Inimitability' Argument for The Qur'an's Divine Origin and The Prophet of Muhammad: Islamic tradition has typically maintained

${ }^{17}$ Ibid., p. 35.

18 Ibid.

${ }^{19}$ See, for example, 'Abd al-Jabbar's 'Book of the Five Fundamentals', in Richard C. Martin et. al, Defenders of Reason in Islam: Mu'tazilism from Medieval School to Modern Symbol (Oxford: Oneworld Publications, 1997), pp. 90-115 (p. 96); and, 'Al-Ghazali's Tract on Dogmatic Theology', edited, translated, annotated and introduced by A. L. Tibawi, Islamic Quarterly, IX (1965), 65-122 (p. 104). 
that the primary miracle of the Prophet Muhammad is the Qur'an. ${ }^{20}$ The miracle of the Qur'an is said to prove that Muhammad is God's Prophet (and ipso facto that there is a God, since Muhammad is God's Prophet only if God exists). Andrew Rippin summarizes the argument from the Qur'an's miraculousness, which originated during the early days of Islam, as follows:

It would appear that, early on, Muslims had to defend their nascent religion against Christian theological attack in the area of the Fertile Crescent, especially Iraq. The following argument was constructed: miracles prove the status of Prophethood and the Qur'ān is Muhammad's miracle; therefore, Muhammad was truly a prophet and Islam is a true, revealed religion. All participants in the debate appear to have agreed on the first premise. What Muslims had to prove, and Christians disprove, was the validity $[$ sic] of the second, for the conclusion, the truth of Islam, stood or fell on its credibility. ${ }^{21}$

As Rippin explains, the controversial premise here is whether the Qur'an is indeed a 'miracle.' The classical Islamic argument that emerged to support this premise is based on the alleged 'inimitability' of the Muslim Scripture. Rippin explains this argument thus:

Over time, the argument became one concerned to prove the 'inimitability' of the Qur'ān, an argument which, its proponents were quick to point out, had a basis in the Qurān itself... [T] he production of a text 'like' the

${ }^{20}$ It is controversial within the Islamic tradition whether the Prophet Muhammad performed any miracles outside of bringing the revelation of the Qur'an. There are numerous ahadith that document Muhammad performing miracles such as splitting the moon, causing water to spring from his hands or multiplying a small quantity of food that fed over one thousand people (see Sahih Al-Bukhari, Volume 5, Book 58, No. 208; Volume 1, Book 4, No. 170 and Volume 5, Book 59, No. 428). The Qur'an, however, seems to strongly suggest that Muhammad performed no miracles apart from conveying the revelation of the Qur'an. In verses 17:90-93, for instance, we read that the unbelievers asked the Prophet to perform miracles, such as causing a spring to gush from the ground or have fragments of heaven fall upon them. In response, Muhammad says that here is merely a messenger. Verses 25:7-8 also note that the unbelievers complained that Muhammad did not come across as extraordinary or a performer of miracles. Based on such Qur'anic data, a number of Muslim thinkers, such as Muhammad Husayn Haykal, have maintained that the revelation of the Qur'an was the only miracle that one can legitimately ascribe to the Prophet Muhammad. See Haykal's The Life of Muhammad (Kuala Lumpur: Academe Art \& Printing Services, 2008), pp. lxxxvi-lxxxvii.

${ }^{21}$ Andrew Rippin, Muslims: Their Religious Beliefs and Practices, Third Edition (London: Routledge, 2005), p. 38. 
Qur'ān is encouraged but known to be impossible: 'Produce a sūra like it [i.e., the Qurān], and call on whom you can, besides God, if you speak truthfully' (Qur'ān 10/38); 'Well then bring ten chapters the like of it, forged!' (Qurān 11/13). God has given the Qurān to Muhammad and because of its divine origin, no text 'like' it can, in fact, be produced. The inimitability of the text proves its divine authorship and thus its status as a miracle, confirming Muhammad's role and the veracity of Islam. ${ }^{22}$

According to Issa J. Boullata, general Muslim consensus maintains that the inimitability of the Qur'anic text refers mainly to its stylistic supremacy, which is held to be all the more remarkable given that the Qur'anic revelation was proclaimed by Muhammad, an illiterate man. ${ }^{23}$ Muslim tradition maintains that this challenge to produce something similar to the Qur'an has never been successfully met since it was first raised. This alleged fact is offered as strong evidence for the divine origin of the Qur'an and the Prophethood of Muhammad.

In reading the Qur'an and ahadith, one gathers the impression that the four sources of epistemic justification I have itemized above see Islamic belief in the existence and oneness of God as well as belief in Muhammad as God's Prophet as being accompanied by very strong epistemic justification. Indeed, at times, the Author of the Qur'an uses an incredulous tone in noting rejection of Islamic belief, as in the following verse: 'How can ye reject the faith in Allah? - seeing that ye were without life, and $\mathrm{He}$ gave you life; then will He cause you to die, and will again bring you to life; and again to Him will ye return.' (2:28) Or again, 'Can there be any doubt concerning Allah, the Creator of the heavens and the earth?' (14:10) It is not surprising then that, for the average Muslim, Islam 'coincides in his mind with the irresistible logic of things', as Frithjof Schuon puts it. ${ }^{24}$ A corollary of this aspect of the Qur'anic Weltanschauung is that the only alternative to having Islamic faith is deliberate and perverse rejection of it; that is to say, having Islamic faith or deliberately and perversely rejecting it are not only two mutually exclusive states of affairs, but they are also, according to the Qur'an, jointly exhaustive. In the Islamic Scripture, there is no room for

22 Ibid.

${ }^{23}$ Issa J. Boullata, 'The Rhetorical Interpretation of the Qur'an: I'jaz and Related Topics' in Approaches to The History of The Interpretations of The Qur'an, Andrew Rippin, (ed.), (Oxford: Clarendon Press, 1988), pp. 139-157 (p. 142).

${ }^{24}$ Frithjof Schuon, Stations of Wisdom (Bloomington, IN: World Wisdom Books, 1961), p. 64, note 1. 
non-belief that arises from, say, ignorance or (sincere) incredulity. ${ }^{25}$ Based on all of this, it seems that epistemic exclusivism, as I have construed it, is indeed a significant component of Traditional Islamic Exclusivism.

\subsection{Salvific Exclusivism}

The final component of what I have termed Traditional Islamic Exclusivism is salvific exclusivism, which I will interpret as follows. A person is a salvific exclusivist with respect to a religion $r$ if and only if, in believing that acceptance of $r$ (or acceptance of its essential doctrines) leads to salvation, she rejects the view that religions other than $r$ can lead to salvation. ${ }^{26}$ A Muslim salvific exclusivist is one who maintains that acceptance of Islam is the only means to salvation; no other religion can offer such salvation. Achievement or loss of salvation, as understood in traditional Islam, is strongly associated with, if not reducible to, a person's entry into paradise or punishment in hell; and, whether a person is 'saved' or not is principally determined by whether he or she responded appropriately to Islamic belief (see e.g. Qur'an 2:82, 3:133, 5:119, 2:24, 4:55-56).

Perhaps the clearest statement of salvific exclusivism in the Qur'an is in verse 3:85: 'And whoever desires a religion other than Islam, it shall not be accepted from him, and in the hereafter he shall be one of the losers.' Now, the Qur'an does contain some verses stating that followers of other religions, such as Judaism and Christianity, will achieve salvation (e.g. 2:62; 5:69). It is difficult to assess what bearing such verses have on the traditional Islamic understanding of salvation, however, for a few reasons. First, these verses, which are few in number, contradict the ethos of the Qur'an as well as the ahadith, which generally subscribes to salvific exclusivism. Second, there are claims in both the Qur'an and ahadith explicitly stating that Jews and Christians will be condemned to hell for their beliefs. Consider, as an example, verses 5:72-73: 'They do blaspheme who say: "Allah is Christ the son of Mary" ... Whoever joins other gods with Allah, - Allah will forbid him the garden, and the Fire will be his abode ... They surely disbelieve who say: Lo! Allah is the third

${ }^{25}$ For more discussion on this, see Imran Aijaz, 'Some Ruminations about Inculpable Non-belief', Religious Studies, Vol. 9, Issue 3 (2013), 399-419, esp. 405-407.

${ }^{26}$ This understanding of salvific exclusivism can easily be modified to refer to specific denominations of religions, world 'philosophies', etc. But such a modification is not required for my purposes in this paper. 
of three; when there is no Allah save the One Allah. If they desist not from so saying a painful doom will fall on those of them who disbelieve.' (see also 98:6) And, in one particular hadith, the Prophet Muhammad is reported to have said: 'By Him in Whose hand is the life of Muhammad, he who amongst the community of Jews or Christians hears about me, but does not affirm his belief in that with which I have been sent and dies in this state (of disbelief), he shall be but one of the denizens of HellFire. ${ }^{27}$ Third, a number of Islamic scholars have maintained that verse 3:85, which affirms that salvation comes through adherence to Islam alone, abrogates those verses that mention the possibility of salvation for non-Muslims, such as Jews and Christians. ${ }^{28}$

A helpful summary account of the traditional understanding of salvific exclusivism in Islam is given by Sheikh Muhammed Salih AlMunajjid, who writes:

Allaah has clearly created everything, sent His blessings on His creation, and sent Messengers and Revealed Books to tell them that whoever believes in and worships Him alone, not associating any partner with Him, will enter Paradise, and whoever denies Him, or worships something else besides Him, or takes other gods instead of Him, or says that He has a wife or son, or that the angels are His daughters, or follows a law other than that which He revealed to judge between people in truth, or turns away from His religion, will be doomed in the Hereafter to the eternal punishment of Hell. This is exact justice, and this will be the fate deserved by the one who did not give his Creator His due. ${ }^{29}$

The thought here seems to be that, given the overwhelming evidence and justification for Islamic belief, religious beliefs and practices contrary to Islamic doctrine must constitute deliberate and perverse denial of the truth. And this, in turns, merits eternal punishment in hell a consequence of God's Justice.

So, here is how the three exclusivist strands in Traditional Islamic Exclusivism - alethic, epistemic and salvific - come together. According

27 Sahih Muslim, Book 1, No. 284, available at: <http://www.hadithcollection.com/ sahihmuslim/129-Sahih\%20Muslim\%20Book\%2001.\%20Faith/8500-sahih-muslimbook-001-hadith-number-0284.html> (last accessed 3/14/14).

${ }^{28}$ See, for instance Al-Tabari's The Commentary on The Qur'an, Volume 1, J. Cooper, (ed.), (Oxford: Oxford University Press, 1989), p. 364.

${ }^{29}$ Sheikh Muhammed Salih Al-Munajjid, 'The Muslim belief concerning the destiny of non-Muslim monotheists in the Hereafter', Islam QA, available at: <http://islamqa. info/en/434> (last accessed 3/15/14). 
to traditional Islamic understanding, there is very good evidence and justification for Islamic belief. Such evidence is available to everyone and points to the truth of God's existence and oneness as well as the Prophethood of Muhammad. Consequently, people should acknowledge the truth of Islamic belief and reject as false those beliefs that are incompatible with it. Those who fail to do this - all non-Muslims - do so because of their obstinate rejection of it $(k u f r)$. Such perverse rejection of Islamic belief merits eternal punishment in hell, as an instance of God exercising His Justice.

\section{TRADITIONAL ISLAMIC EXCLUSIVISM CRITIQUED}

In this section, the central thesis around which I will form my assessment of, and arguments against, Traditional Islamic Exclusivism is that it is highly implausible. I will begin by arguing that Islamic epistemic exclusivism is not tenable. My case against it will consequently open up a line of criticism against Islamic salvific exclusivism. Finally, I will assess what implications my views regarding epistemic and salvific exclusivism have for alethic exclusivism in an Islamic context.

\subsection{Problems with Islamic Epistemic Exclusivism}

As we have seen, the Islamic epistemic exclusivist affirms two key claims. First, there is (strong) epistemic justification for Islamic belief - belief in the existence and oneness of God, alongside belief in Muhammad as God's Prophet. Second, there is little, if any, epistemic justification for beliefs that are incompatible with Islamic belief. I will consider these two claims in turn, starting with an assessment of the four alleged sources of epistemic justification for Islamic belief.

To begin with, the claim that belief in the existence and oneness of God is our original, natural disposition (fitrah) seems, on the face of it, patently false. Perhaps the most obvious objection to it is that it appears to be incompatible with a number of facts about our global religious landscape. ${ }^{30}$ Consider, the fact that there are plenty of people in the world who do not believe that there is a God or that there is only one God. As of 2010, there were 500 million Buddhists in the world, people

30 See 'The Global Religious Landscape, Pew Research Center Forum on Religion \& Public Life, available at: <http://www.pewforum.org/2012/12/18/global-religiouslandscape-exec/> (last accessed 3/26/14). 
who do not believe in the existence of any being like Allah. ${ }^{31}$ Consider also the fact that Christianity and Hinduism, religions whose members typically reject the Islamic claim that God is strictly one, collectively had a total of 3.2 billion followers. ${ }^{32}$ Indeed, the specific Islamic belief in the existence and oneness of God seems to be held by only a minority of the world's population..$^{33}$ Based on these data, one can construct the following argument: (1) If belief in the existence and oneness of God is our natural disposition, we would not see such diversity in beliefs about religion. Given that (2) we do, however, see such diversity, one can conclude that (3) belief in the existence and oneness of God is not our natural disposition. How might one reply to this argument? Well, given the validity of its modus tollens form, and the obvious truth of the second premise, the only recourse left for someone who wants to rationally resist accepting the argument's conclusion is to reject the first premise.

One way to do this is by arguing that the Islamic understanding of God's existence and oneness can be found in all of the various world religions and philosophies, albeit in ways that are subtle. For instance, it may be argued that, underneath layers of theological embellishments and aberrations in their respective religions, Jews, Christians, Sikhs and members of other theistic worldviews do, in fact, believe in the existence and oneness of God. Such a move is, however, problematic, for at least two reasons. First, although the beliefs of some, such as Jews and Christians, can perhaps be accommodated into the Islamic understanding of God's existence and oneness (despite the evidence cited above to the contrary), it will take quite a stretch of imagination to do this for the beliefs of others, such as Buddhists, Jains and adherents of non-theistic religions and philosophies. It is hard to see, for instance, how the Buddhist religion can be described as essentially Muslim, given the Buddhism's explicit denial of theism. Connected to this is the hermeneutical problem of accounting for those portions of the Islamic texts that explicitly repudiate other religions and philosophies because of their denial of God's existence and oneness. ${ }^{34}$

Another way to attempt to reconcile the traditional Islamic understanding of fitrah with some of the facts about religious diversity

\footnotetext{
${ }^{31}$ Ibid.

32 Ibid.

${ }^{33}$ In the study conducted by the Pew Research Center, the population of Muslims in the world as of 2010 was 1.6 billion, or $23 \%$ of the world's population.

${ }^{34}$ See section 2.3 above.
} 
cited above is to try and discredit those beliefs incompatible with Islamic belief by maintaining that they arise (merely) due to social conditioning or sin (or both). The idea here is that although everyone is born in a state of fitrah, social conditioning or sin prevents people from responding appropriately to their innate nature; and, it is this responding inappropriately that regrettably results in the kind of religious diversity that we see today. Here is how Sheikh 'Abd al-Rahmaan al-Barraak explains this:

What it means when it is said that a child is born as a Muslim is that he is born inherently ready, when he reaches the age of discretion, if he is given the choice between Islam and its opposite, to prefer Islam over its opposite and to choose Islam as his religion, so long as there is nothing to prevent him from doing so, such as his whims and desires or tribalism. Following his desires makes him prefer falsehood so that he may attain some share of leadership or wealth, and tribalism or racial pride makes him follow his forefathers or elders, even if they are not following true guidance. ${ }^{35}$

This response essentially maintains that an informed, reasonable rejection of Islamic belief is not possible. Those engaging in religious practices that are incompatible with Islam are motivated primarily by vices such as whims and desires, tribalism, racial pride, etc. It is difficult to avoid seeing this sort of reply as merely dogmatic, especially when it seems that it cannot be supplemented by an argument that does not beg the question. ${ }^{36}$ Not only that, but it relies on claims that are simply not plausible. Surely, there are plenty of cases involving informed, reasonable rejection of Islamic belief. Let us just consider the theistic component of Islamic belief. In 2009, David Bourget and David Chalmers conducted a survey of 1,972 philosophers in 99 leading departments of philosophy. ${ }^{37}$ The found that $72.8 \%$ of the philosophers surveyed either accepted or

${ }^{35}$ Islam QA, 'What is the fault of children born in a kaafir environment?', available at: $<$ http://islamqa.info/en/11783> (last accessed 3/27/14).

36 Here, Karl Barth's famous interview comes to mind, where he declares that Hinduism is a form of unbelief and that Hindus are in rebellion against God. When asked how he knew this, since he had never previously met a Hindu, Barth replied that he knew this 'a priori'. As cited in James Lee Fredericks, Faith Among Faiths: Christian Theology and Non-Christian Religions (Mahwah, New Jersey: Paulist Press, 1999), p. 21.

${ }^{37}$ David Bourget and David Chalmers, 'What do philosophers believe?', Philosophical Studies (December, 2013), pp. 1-36. 
leaned towards atheism. ${ }^{38}$ Are we to think, then, that most philosophers today who are atheistic are simply irrational in their rejection of theism, or that their dismissal of theism is motivated simply by whims and desires, tribalism or racial pride? Are there no reasonable philosophers, those like the late J.L. Mackie, for instance, who predicate their rejection of God's existence on a careful consideration of the evidence ${ }^{39}$ Answering these questions in the negative not only seems implausible ${ }^{40}$ but comes across as the epitome of close-mindedness. Furthermore, there is no independent evidence suggesting that the beliefs of all non-Muslims who do not accept Islamic belief can be explained by appealing to social conditioning or sin. Indeed, there is evidence to the contrary. Consider once again the family of philosophers, many of whom are trained specifically to avoid basing their convictions on beliefs that are popular, traditional, politically correct, emotionally appealing, etc. Indeed, in its history, argument forms like appeal to popularity, appeal to tradition, appeal to emotion, etc., have long been recognized as fallacious in logic - a core component in the study of philosophy. To be sure, this does not mean that sociological factors have no influence on the work done by philosophers, but it does suggest that a blanket dismissal of what philosophers believe (e.g. that God does not exist), by appealing to social conditioning, is not plausible.

But what of sin as a viable explanation of the beliefs of non-Muslims, beliefs that are incompatible with Islamic belief? If the reference to sin is taken to refer primarily to moral vices such as pride (a cardinal sin in Islam; see e.g. Qur'an 2:34) that prevent people from recognizing their being in a state of fitrah, then we are lead to what I call 'The Gandhi Problem'. This problem essentially concerns reconciling (1) the view that

${ }^{38}$ Ibid. $14.6 \%$ accepted or leaned towards theism, while $12.6 \%$ accepted or leaned towards the option of 'other'.

${ }^{39}$ Mackie's The Miracle of Theism (Oxford: Oxford University Press, 1983) is widely regarded among philosophers as one of the best works in philosophy of religion from an atheistic perspective. In his review of the book, Robert Adams (himself a theist) calls Mackie's work 'a book that will surely rank for some time among the best of philosophical "apologies" for atheism. The standard of exposition and argument is high, and Mackie's fair-mindedness is exemplary. He critically, but in many ways sympathetically, examines an impressive array of theistic arguments', Robert Merrihew Adams, Review of 'The Miracle of Theism, The Philosophical Review, Vol. 95, No. 2 (April, 1986), 309-316 (p. 309).

${ }^{40}$ Especially in light of some of the criticisms of the Islamic arguments for the existence of God mentioned below. 
non-Muslims who hold beliefs incompatible with Islamic belief do so because of their sin, despite the fact that (2) many such non-Muslims are morally upright and virtuous individuals, people such as Mahatma Gandhi (a Hindu) or Mother Teresa (a Catholic). The more general version of this problem states that non-Muslims who do believe in things contrary to Islamic belief do not appear to be stubbornly resisting the Islamic religion our of pride, selfishness, etc. Rather, they simply do not hold Islamic belief. ${ }^{41}$

So, until further argument can be given to the contrary, the claim that belief in the existence and oneness of God is our original, natural disposition seems untrue. Facts about religious diversity suggest that (Islamic) theism is not epistemically privileged in the way that the concept of fitrah would have us believe.

My treatment of The Islamic Anthropological Argument will be brief, simply because, outside of the traditional Islamic account of it, there is no external historical evidence supporting the idea that every nation on earth was sent a messenger calling people to (return to) Islamic monotheism - the primordial core of all world religions and philosophies. The traditional Islamic view is very similar to the hypothesis of 'primitive monotheism' (Urmonotheismus), presented and defended by thinkers like Andrew Lang and Wilhelm Schmidt over a century ago. ${ }^{42}$ In essence, this hypothesis maintains that all world religions and philosophies that are not monotheistic degraded from a monotheistic Urreligion, which consisted of belief in a deity who is eternal, the creator, omniscient and beneficent. ${ }^{43}$ One problem with this hypothesis is that we do not have the means to fully assess its historical credibility. ${ }^{44}$ Another problem with it is that there are alternative and better hypotheses that account for the origin and development of religion, such as the evolutionary theory. Not only is this particular theory supported by strong evidence, but it also contradicts the notion of an Urmonotheismus by placing monotheism at

${ }^{41}$ For further discussion of this particular point, see Aijaz, 'Some Ruminations about Inculpable Non-belief', pp. 12-19.

${ }^{42}$ Mircea Eliade, The Quest: History and Meaning in Religion, (Chicago, IL: University of Chicago Press, 1984), pp.23-24.

43 Ibid., p. 24.

${ }^{44}$ Ibid., p. 25. For a summary account of some of the problems with Lang and Schmidt's work, see E.E. Evans-Pritchard, Theories of Primitive Religion (Oxford: Clarendon Press, 1965), pp. 103-105. 
the end of a long line of religious evolution. ${ }^{45}$ These are just two problems facing anyone who wants to defend the Islamic Anthropological Argument along the lines of the hypothesis of an Urmonotheismus.

Turning now to the Qur'anic arguments for the existence and oneness of God, these arguments come across as superficial and unconvincing, being susceptible to criticisms that are familiar in the Philosophy of Religion. The Argument from Providence fails because it relies on premises that are at best questionable and its conclusion does not carry much weight in providing evidence for Islamic monotheism. Consider the first premise of this argument, which states that all existing things (found in the world) are suited to our existence. This is clearly false, as a moment's reflection on instances of apparent dysteleology and evil in the world will suggest, e.g. suffering and death caused by diseases, harsh environmental conditions, natural disasters, etc. Such reflection also calls into question the assumption of anthropocentrism that underlies the argument, an assumption that is especially questionable in light of evolutionary biology, according to which human beings have emerged much later as a species, being preceded by bacteria, cockroaches and dinosaurs. Be that as it may, even if we were to accept the argument as sound, it would prove, at best, the existence of some sort of intelligent agency behind the creation of the universe. 'But beyond that position', as Hume famously notes, the defender of such an argument 'cannot ascertain one single circumstance, and is left afterwards to fix every point of his theology, by the utmost license of fancy and hypothesis. ${ }^{36}$ The Argument from Invention so obviously begs the question that there is no need to proffer anything further by way of criticism to show that it fails. The first premise of the argument states that all existing things (animals, plants, etc.) are invented. But in order to accept this premise, one already needs to be committed to the truth of the argument's conclusion, which states that there is an Inventor (i.e. God) of every existing thing in the world. The sort of argument for God's oneness that is found in the Qur'an is principally motivated by the thought that the existence of more than one divine being would (or could) result in one divine being frustrating the will of the other(s); and this, in turn, would (or could) result in chaos

${ }^{45}$ Lucius Boraks, Religions of The East (Kansas City, MO: Rowman \& Littlefield, 1988), p. 9.

46 David Hume, Dialogues Concerning Natural Religion [1779], ed. Martin Bell (London: Penguin, 1990), p. 79. 
and disorder in the universe. But, as Richard Swinburne has argued, it not at all clear that the existence of multiple deities necessarily means that they will fail to 'work things out', so to speak, in a way that the activity of one deity does not interfere with what the other(s) do. ${ }^{47}$ The Qur'anic arguments for the existence and oneness of God are, therefore, problematic and consequently fail to supply epistemic justification for the belief that (only one) God exists.

It may be objected here that I have discussed only simple or superficial formulations of these arguments and that there are more sophisticated variants out there. For instance, the spirit of The Argument from Providence, as distilled from the Qur'an and formulated by Ibn Rushd, can be found in the more 'updated' Fine-Tuning Argument that rests on recent discoveries about the fundamental physical structure of our universe. ${ }^{48}$ Although this is true, it should be noted that the simplistic nature of the Qur'anic arguments for the existence and oneness of God is something that is displayed to its reader from a straightforward reading and interpretation of the Islamic text, as opposed to being, say, a gross oversimplification of more sophisticated arguments contained therein. What is more, merely shifting the focus to more sophisticated versions of the Qur'anic arguments leaves untouched and therefore intact my contention that the original, simple formulations are unconvincing, as I have argued. The import of this last point is significant since a great many traditional Muslims today do think that the original, simple formulations of the arguments for God's existence and oneness found in the Qur'an are successful. As W.M. Watt writes, commenting more generally on the traditionalist Muslim's attitude towards faith and reason:

Traditionalist Muslims today like to claim that 'Islam is a religion based on reason'; but if asked to elaborate this point, they can only produce the sort of philosophical reasoning that was in vogue in the twelfth century ... [T] hey know of no philosophy since Averroes, and are completely unaware of the new challenges to religious belief produced by men like Hume and Feuerbach, not to mention our twentieth-century [now twenty-first century] philosophers. ${ }^{49}$

${ }^{47}$ Richard Swinburne, The Coherence of Theism, Revised Edition (Oxford: Clarendon Press, 1993), p. 233.

${ }^{48}$ See, for instance, Robin Collins' 'God, Design, and Fine-Tuning', available at: $<$ http://home.messiah.edu/ rcollins/Fine-tuning/Revised\%20Version\%20of\%20Finetuning\%20for\%20anthology.doc $>$ (last accessed 4/1/2014). 
Even contemporary defenders of traditionally simple theistic proofs acknowledge (even if implicitly sometimes) that such proofs require more updated and sophisticated defences. Consider as just one example the well-known Kalam Cosmological Argument, ${ }^{50}$ formulated by medieval Muslim thinkers like Al-Ghazali. In his Jerusalem Epistle, AlGhazali states the argument as follows: 'It is self-evident to human reason that there must be a cause for the origination of anything originated. Since the universe is originated it follows that there was a cause for its origination. ${ }^{51}$ William Lane Craig, the foremost contemporary proponent of this argument, concedes that his defence of the argument's premises

took [him] into extended discussions of such recondite and profound subjects as Cantorian set theory, transfinite arithmetic, the ontological status of sets, the nature of time as tensed or tenseless, Zeno's Paradoxes, Kant's First Antinomy, contemporary Big Bang cosmology (including critiques of alternative or non-standard cosmological theories such as the Steady State model, the Oscillating model, the Vacuum Fluctuation model, and Quantum Gravity models), thermodynamics and physical eschatology, and so on and so forth..$^{52}$

Craig explains that, although the overall logic of the argument is extremely simple, establishing the truth of the premises can be 'a long and complex affair. ${ }^{53}$

Simplistic arguments for the existence and oneness of God of the sort that are found in the Quran are just not convincing, especially in our present day after thinkers like Hume, Kant, Darwin, etc., have criticized the plausibility of theistic arguments and explanations. But what about the more 'sophisticated' theistic proofs in contemporary Philosophy of

49 W.M. Watt, Islamic Fundamentalism and Modernity (London: Routledge, 1988), p. 5 .

50 The label is William Lane Craig's. See his 'The Existence of God and The Beginning of The Universe', available at: <http://www.reasonablefaith.org/the-existence-of-godand-the-beginning-of-the-universe $>$ (last accessed 4/1/2014).

${ }^{51} \mathrm{Al}$-Ghazali, 'The Jerusalem Epistle', a dual language edition with English translation and commentary published as: 'Al-Ghazali's Tract on Dogmatic Theology', edited, translated, annotated and introduced by A. L. Tibawi, Islamic Quarterly, IX (1965), 65122 (p. 98).

52 William Lane Craig, 'A Swift and Simple Refutation of The Kalam Cosmological Argument?', available at: <http://www.reasonablefaith.org/a-swift-and-simplerefutation-of-the-kalam-cosmological-argument> (last accessed 4/1/2014).

${ }^{53}$ Ibid. 
Religion? It seems fair to say that whether these proofs are successful is controversial, not only in the Philosophy of Religion, where there is no consensus regarding their success (or failure), but also amongst members of the general public. As Robert McKim observes,

It is obvious that for every Richard Swinburne who adds up what he thinks to be the relevant evidence and gets a result that supports theism, there is a J.L. Mackie who gets an entirely different result, and, in general, for every theist to whom the facts of her experience appear to confirm that God exists there are apparently equally well qualified nontheists, including members of nontheistic religions, agnostics, and atheists, to whom the facts of their experience have no such significance. ${ }^{54}$

In any case, the Qur'anic arguments for the existence and oneness of God are, in their simple, original forms, unsuccessful. They do not, therefore, provide epistemic justification for Islamic belief.

The 'Inimitability' Argument for the Qur'an's divine origin is, much like The Islamic Anthropological Argument, one that lacks any external, corroborating evidence. The conclusion of this argument is that the Qur'an is a miracle and the key supporting premise is that the text of the Qur'an - conveyed to use by Muhammad, an illiterate man - is inimitable. One problem with this argument is that the concept of a 'miracle' used in the conclusion is not the classical one we find in Hume, for whom a miracle is 'a transgression of a law of nature by a particular volition of the Deity, or by the interposition of some invisible agent. ${ }^{55}$ As Ibn Rushd notes in his Incoherence of The Incoherence, the miracle of the Qur'an does not involve 'an interruption in the course of nature ... like the changing of a rod into a serpent, but ... is established by way of perception and consideration for every man who has been or will be till the day of resurrection, ${ }^{56}$ If the idea of violating the laws of nature is built into the definition of a miracle, then it is understandable why a miracle can be seen as providing some evidence for the existence of a God. For, is seems that only something like a God could explain the violation of a law of nature that is confirmed to hold universally. But if an alleged

${ }^{54}$ Robert McKim, Religious Ambiguity and Religious Diversity (Oxford: Oxford University Press, 2001) p. 24.

${ }^{55}$ David Hume, 'Of Miracles', An Enquiry Concerning Human Understanding, available at: <http://www.bartleby.com/37/3/14.html> (last accessed 4/6/2014).

${ }^{56}$ Ibn Rushd, Simon van den Bergh, (trans.), Averroes' Tahafut Al-Tahafut (London: Trustees of the E.J.W. Gibb Memorial, 1978), p. 315. 
'miracle' does not violate any laws of nature, then it becomes difficult to ascertain its evidential value. This is basically Swinburne's objection to the Islamic 'miracle' of the Qur'an. 'We have no reason to suspect that that illiterate creative genius cannot guess at truths normally accessible only to the literate,' as Swinburne says, 'or create a new religious style or movement. ${ }^{57}$ This point becomes all the more forceful if we consider the premise of the argument from the Qur'an's inimitability. The claim that the text of the Qur'an is stylistically inimitable is an aesthetic judgment and it is controversial whether such judgments are objective and can be evaluated according to objective criteria. ${ }^{58}$ Moreover, it is clearly controversial what kind of aesthetic merit in a work counts as a mark of divine inspiration. No traditional Muslim would, for instance, regard the works of Shakespeare, Shelley or Keats as divinely inspired. But why not? What aesthetic difference is there between, say, Shelley's Ozymandias and one of the short chapters towards the end of the Qur'an, such that the former fails to qualify as divine inspiration while the latter does? It is difficult to see how one can answer this question without sliding into subjective and arbitrary aesthetic judgments. The fact that, outside of the Muslim community, there is no consensus among Arabic-speaking people regarding the stylistic inimitability of the Qur'an further supports this point. I am therefore in agreement with Rippin's description of the argument from the Qur'an's inimitability as a 'dogmatic one, essential to the proof of the status of the text, but one which operates (like many other religious arguments) within the presuppositions of Islam alone. ${ }^{59}$

In sum, then, none of the four alleged sources of epistemic justification for Islamic belief succeed in showing that the Muslim belief in God's existence and oneness, along with belief in the Prophethood of Muhammad, is epistemically justified. This component of Islamic epistemic exclusivism is therefore false. The Islamic denial of similar epistemic justification for beliefs that are incompatible with Islamic beliefs is not a significant concern, given my purposes in this paper. I will, however, note the following point. If epistemic justification for Islamic belief is lacking, then people who are non-Muslim cannot

57 Richard Swinburne, Revelation: From Metaphor to Analogy, Second Edition (Oxford: Oxford University Press, 2007), p. 128.

${ }^{58}$ See Oliver Leaman, Islamic Aesthetics: An Introduction (Notre Dame, IN: University of Notre Dame Press, 2004), p. 142.

${ }^{59}$ Rippin, Muslims: Their Religious Beliefs and Practices, pp. 39-40. 
be regarded as perversely rejecting what they know (or, at least, are epistemically justified in believing) to be true. This observation dovetails with facts in our experience that are evident. There are plenty of people around us who cannot be regarded as obstinately rejecting Islamic belief. More specifically, there are people of integrity, people who are, that is, wise, careful and judicious thinkers, intelligent, clever, honest, reflective, serious, etc., who hold beliefs that are incompatible with Islamic belief. ${ }^{60}$ The idea that all non-Muslims can be regarded as kafir, walking around with their heads held high and stubbornly rejecting Islamic belief, which they know to be true, is simply a theological fantasy.

\subsection{Problems with Islamic Salvific Exclusivism}

If the criticisms of Islamic epistemic exclusivism in the previous section are correct, then we have arrived at two important conclusions. First, Islamic belief - that is, belief in the existence and oneness of God as well as Muhammad's Prophethood - lacks epistemic justification. Second, and consequently, the Qur'anic stance that non-Muslims are kafirs, i.e. perversely rejecting Islamic belief, is implausible. As noted in the preceding section, the concept of the kafir is, in the Qur'an, conceptually tied to all cases where a person fails to respond appropriately to Islamic belief. That is, a person who does not practice Islamic belief fails to do so out of a stubborn refusal to acknowledge what he knows (or at least has strong epistemic justification for believing) to be true. It is clear from reading the Qur'an that possessing strong epistemic justification is a necessary condition for being in a state of kufr. If, however, Islamic belief lacks epistemic justification (and therefore cannot constitute a case of knowledge either), ${ }^{61}$ then it follows that no non-Muslim is in a state of $k u f r$. If a non-Muslim cannot be labelled as a kafir, then this has serious ramifications for salvific exclusivism in Islam.

As noted previously, according to the traditional Islamic understanding of salvific exclusivism, failure to achieve salvation is treated as equivalent to condemnation in hell. The main reason that the Qur'an cites for people's eternal punishment in hell is that they refused to acknowledge the truth of Islamic belief. Each inhabitant of hell is a kafir.

${ }^{60}$ The description of 'people of integrity' here comes from Robert McKim, Religious Ambiguity and Religious Diversity, p. 129.

${ }^{61}$ According to most epistemologists, epistemic justification is at least a necessary condition for knowledge. 
Now, this particular aspect of Islamic salvific exclusivism opens itself up to criticism in at least two different ways.

First, one can criticize whether the traditional understanding of hell in Islam is compatible with God's Compassion and Mercy, which is stressed throughout the Qur'an. Taken at face value, the Qur'anic descriptions of the punishment that awaits those who reject God are, quite frankly, sadistic and horrifying, to say the least. Let me just consider a few verses here. First and foremost, the main description of hell in the Qur'an is a fire whose fuel is men and stones (2:24). God will ensure that the blazing fire of hell never subsides (17:97). It is eternal and inescapable (5:37). As soon as the fire of hell finishes roasting the skin of its inhabitants, God will create new skins for them to continue the cycle of punishment (4:56). People in hell will have their foreheads, flanks and backs branded. They will be given purulent water to drink, which they will be able to sip but not swallow (14:16-17). They may also be given boiling water that will tear their bowels (47:15). The thirsty who ask for drink will be showered with water that is like molten lead, scalding their faces (18:29). Many more such verses can be cited, all of which effectively portray hell as a gruesome torture chamber and the God that created it as a God of (excessive!) retribution. Now, even if each inhabitant of hell is a kafir, the Qur'an's description of God's punishment awaiting such a person simply does not seem reconcilable with His Compassion and Mercy. Indeed, even if this point is considered with respect to God's Justice alone, where a person did not acknowledge His Creator appropriately and give Him 'His due' as Sheikh Al-Munajjid suggests, it is hard to see how this sort of punishment is fair. At most, the kafir refuses to acknowledge God and sin for a hundred years or so, an infinitesimal flicker in the timeline of creation from the perspective of an eternal deity. In response, God retaliates disproportionately by condemning the kafir to horrific forms of torture, eternally. In thinking about all this, one has ample reason for taking seriously the idea that perhaps a literal interpretation of verses that describe hell in the Qur'an is wrong. Perhaps, as Muhammad Ali suggests, the doctrine of hell should understood as remedial (by taking mention of the fire of hell as a metaphor for purification) rather than retributive. ${ }^{62}$

${ }^{62}$ Muhammad Ali, The Religion of Islam (Cairo: National Publication \& Printing House, 1967), p. 307. 
Rather than pursue this line of criticism, which certainly has force, another simple argument against Islamic salvific exclusivism is to point out that, whatever the Qur'an may say about the fate of the kafir in hell and however plausible or not this may be, it is simply inapplicable to the situation of non-Muslims in our world. Why? Because a non-Muslim, as noted, cannot be regarded as a kafir. It remains an open question, then, whether non-Muslims who hold beliefs that are incompatible with Islamic belief may be saved. Surely, given the Islamic understanding of God as Gracious, Merciful, Forgiving, etc., such a possibility has to be taken seriously. Rejecting it gives rise to the sort of point that Hick makes several times in his work:

[T] the basic criticism of both Christian and Muslim [salvific] exclusivism is that it denies by implication that God, the sole creator of the world and of all humanity, is loving, gracious and merciful, and that His love and mercy extend to all humankind. If God is the creator of the entire human race, is it credible that God would set up a system by which hundreds of millions of men, women and children, the majority of the human race, are destined through no fault of their own to eternal torment in hell? ${ }^{63}$

Hick's basic criticism here can be further strengthened by noting that, at least as far as Islamic salvific exclusivism is concerned, non-Muslims are not guilty of $k u f r$.

\subsection{Islamic Alethic Exclusivism}

It should be clear that my criticisms of both Islamic epistemic and salvific exclusivism have no bearing on alethic exclusivism in Islam. As explained earlier, exclusivism with respect to truth is both a basic principle of rationality and grounded in a natural interpretation of the Qur'an (see section 2.1). A person can, however, be an alethic exclusivist in an Islamic context while rejecting the traditional Islamic understanding of both epistemic and salvific exclusivism (of course, which religious propositions the Muslim alethic exclusivist affirms and denies may change in light of the criticisms proffered in this paper!). Equivocating on the different forms of religious exclusivism can lead to confusion. A clear example of such equivocation and confusion can be found in Gavin D'Costa's criticism of Hick's pluralism. D'Costa argues

${ }^{63}$ John Hick, 'Religious Pluralism and Islam', available at: <http://www.johnhick.org. uk/article11.html> (last accessed 4/6/2014). 
that religious pluralism must always be a form of exclusivism and that nothing called pluralism really exists. This is because even the religious pluralist holds some form of truth criteria and anything that falls short of that criteria is not true. In this regard, religious pluralism and exclusivism operate within the same logical structure. ${ }^{64}$ But this sort of objection fails to take into consideration the fact that both religious exclusivism and pluralism can be understood with reference to a number of other issues such as epistemic justification and salvation, alongside the question of truth.

\section{CONCLUSION}

Religious exclusivism, especially the version that I have termed Traditional Islamic Exclusivism, has a number of philosophical, theological and practical implications. Thinking carefully about the practical implications is especially important today, where the Islamic religion is facing increasing scrutiny because of the religiously inspired, but morally questionable, actions of many Muslims. To consider just one recent example, in 2012 Afghan senators wanted to remove the word 'friendship' in a pact with France based on their belief that Muslims cannot be friends with infidels. ${ }^{65}$ Several other examples can be cited where morally questionable or wrong actions by Muslims were inspired by their commitment to Traditional Islamic Exclusivism. The vast majority of Muslims in the world, of course, live their lives peacefully. What they may not recognize, however, is that their actions are not congruent with the traditional Islamic understanding of religious exclusivism. For this, they are often shunned by Imams from the pulpits in the mosques who argue that, in light of Islamic theology, Muslim practice needs to change (e.g. no mingling with non-Muslims, taking them as friends, etc.). But perhaps it is not the religious practice of most Muslims that needs to change, but, rather, their traditional understanding of Islamic theology, including religious exclusivism.

\footnotetext{
${ }^{64}$ Gavin D'Costa, 'The Impossibility of A Pluralist View of Religions', Religious Studies, Vol. 32, Is. 2 (1996), 223-32 (pp. 225f.).

65 The Telegraph, 'Afghan bid to "de-friend" France', October 3 2012, available at: $<$ http://www.telegraph.co.uk/news/worldnews/asia/afghanistan/9584584/Afghan-bidto-de-friend-France.html (last accessed 4/6/2014).
} 